\title{
VIDEO EDUKASI PENCEGAHAN PENYEBARAN VIRUS CORONA DI PROVINSI MALUKU UTARA
}

\author{
Lita Asyriati Latif ${ }^{1}$, Sandi Rais ${ }^{2}$, Bambang Tjiroso ${ }^{3}$ \\ 1,2,3 Jurusan Teknik Mesin, Fakultas Teknik Universitas Khairun, Ternate \\ email: lithalatif@yahoo.com, sansandyfti@yahoo.com, bambangtjiroso@unkhair.ac.id
}

\begin{abstract}
ABSTRAK
Pembuatan video edukasi pencegahan penyebaran virus corona ini bertujuan untuk memberikan informasi yang benar kepada masyarakat dan pengetahuan tentang pencegahan penyebaran virus corona mulai dari penggunaan masker, mencuci tangan, pembatasan sosial, jarak aman penularan virus corona, menjaga imunitas agar kebal terhadapa virus corona dan bagaimana peran mahasiswa untuk memberikan penyuluhan kepada masyarakat tentang cara-cara pencegahan penyebaran virus corona tersebut di atas. Pembuatan video ini dilakukan dalam beberapa tahapan antara lain; Pembuatan Skrip Video yang merupakan alur cerita dari sebuah film dengan beberapa tahapan pengambilan video serta artis-artis pendukung pada video ini. Video edukasi COVID 19 dibuat dengan durasi 6,28 menit dengan melibatkan 8 orang artis pendukung yaitu 7 orang mahasiswa dan 1 orang Dosen yang diwaliki oleh Pembantu Dekan III Fakultas Teknik. Video ini diambil dengan menggunakan digital camera dan drone. Editing video menggunakan software Adobe Premiere Pro 2020 v.14.5 yang memiliki banyak smart tool dan dapat direkam dalam format apapun termasuk 8K dan virtual reality. Publishing video dilakukan melalui beberapa media sosial antara lain YouTube, Facebook, Instagram dan WhatsApp, 111 view dan 15 like didapatkan semenjak di publish pada 29 Mei 2020 di media YouTube serta tanggapan positif dan video share oleh beberapa mahasiswa dan dosen setelah dipublish di halaman Facebook Fakultas Teknik dan Instagram.
\end{abstract}

Kata Kunci: Covid-19, Video Edukasi, Penyuluhan, Media sosial, Maluku Utara.

\begin{abstract}
The making of this educational video to prevent the spread of the corona virus aims to provide correct information to the public and knowledge about preventing the spread of the corona virus, starting from the use of masks, washing hands, social restrictions, safe distance for the transmission of the corona virus, maintaining immunity to be immune to the corona virus and how it plays a role. students to provide education to the public about ways to prevent the spread of the corona virus above. The making of the video itself was carried out in several stages, including; Making a Video Script, which is a storyline of a film with several video shooting stages and supporting artists in this video. The COVID 19 educational video was made with a duration of 6.28 minutes involving 8 supporting artists, namely 7 students and 1 lecturer who was represented by the Assistant Dean III of the Faculty of Engineering. This video was taken using a digital camera and a drone. Video editing uses Adobe Premiere Pro 2020 v.14.5 software which has many smart tools and can be recorded in any format including 8K and virtual reality. Video publishing is carried out through several social media including YouTube, Facebook, Instagram and WhatsApp, 111 views and 15 likes have been obtained since being published on May 29, 2020 on YouTube as well as positive responses and video shares by several students and lecturers after being published on the Faculty Facebook page. Engineering and Instagram.
\end{abstract}

Keywords: Covid-19, Educational Videos, Counseling, Social Media, North Maluku 


\section{PENDAHULUAN}

Di Wilayah Indonesia sendiri Gugus Tugas penanganan Covid-19 mengumumkan bahwa jumlah kasus Covid-19 di Indonesia sudah mencapai total 7.418 pasien positif Covid-19. Sebanyak 635 pasien meninggal dunia dan 913 pasien sembuh. Melalui konferensi pers resmi Badan Nasional Penanggulangan Bencana (BNPB), Juru Bicara Covid-19 Ahmad Yurianto mengingatkan kepada masyarakat untuk tidak bepergian dan tidak mudik ke kampung halaman. Yuri mengatakan tidak bepergian ataupun mudik ke kampung halaman adalah tindakan terbaik untuk menjaga diri, keluarga, juga orang lain di sekitar agar tetap sehat.

Berbagai upaya pencegahan penyebaran virus corona sudah banyak dilakukan baik oleh pemerintah maupun sektor swasta. Respon masyarakat untuk berpartisipasi aktif dalam pencegahan penyebaran Covid-19 dengan mematuhi himbauan pemerintah untuk menjalankan protokol kesehatan belum cukup optimal (Buana, 2020). Seluruh masyarakat ikut berpartisipasi dalam membantu sesamanya yang mengalami keterpurukan ekonomi pada masa pandemi ini. Sebagai upaya partisipasi penanganan pencegahan virus corona ini, Fakultas Teknik Universitas Khairun merasa terpanggil untuk ikut berpartisipasi. Partisipasi pencegahan penyebaran Virus Corona oleh Fakultas Teknik Universitas akan dilakukan dalam bentuk pembuatan video edukasi dengan Judul: "Peran Mahasiswa Sebagai Garda Terdepan Pencegahan Virus Corona"

Pembuatan video edukasi pencegahan penyebaran virus corona ini bertujuan untuk memberikan informasi yang benar kepada masyarakat dan pengetahuan tentang pencegahan penyebaran virus corona mulai dari penggunaan masker, mencuci tangan, pembatasan sosial, jarak aman penularan virus corona, menjaga imunitas agar kebal terhadap virus corona dan bagaimana peran mahasiswa untuk memberikan penyuluhan kepada masyarakat tentang cara-cara pencegahan penyebaran virus corona tersebut.

\section{METODE}

\section{Tempat dan Waktu Pembuatan Video}

1. Tempat pengambilan video akan di lakukan di lingkungan Universitas Khairun Ternate dan di Pelabuhan Transportasi antar Pulau Provinsi Maluku Utara. Editing video dilakukan di LAB CAE Fakultas Teknik, Universitas Khairun Ternate.

2. Waktu Pelaksanaan pembuatan video edukasi pencegahan penyebaran virus corona dilaksanakan mulai pada tanggal 1 Mei 2020. 


\section{Alat dan Editing Software}

Peralatan dan software yang digunakan dalam pembuatan video edukasi Covid 19 ini antara lain

1. Camera Digital (Canon 5D Mark II9)

2. Drone DJI Mavic Pro. II

3. Tripot XC5 Fotopro

4. Adobe Premiere Pro 2020 ver. 14.5

\section{Metode Pelaksanaan Tahapan Pembuatan Video}

Adapun tahapan pembuatan video edukasi ini akan dilakukan dalam beberapa tahapan sebagai berikut:

1. Pembuatan Skrip Video yang akan di ambil

Pada tahap ini akan dibuatkan Skrip atau alur pengambilan video, penentuan artis yang akan masuk dalam video serta lokasi pengambilan video.

2. Tahapan Pengambilan Video

a. Pengambilan video 7 orang mahasiswa Fakultas Teknik Universitas Khairun yang memberikan Edukasi kepada masyarakat.

b. Pengambilan Video Himbauan Pencegahan COVID 19 oleh Pembantu Dekan III Fakultas Teknik Universitas Khairun, Nani Nagu ST., MT.

c. Pengambilan Video Masyarakat yang terdampak COVID 19.

3. Video Editing

Pada tahap ini dilakukan penggabungan dan editing video-video yang telah di ambil.

4. Publishing

Pada tahap ini video yang telah selesai dibuat, akan dipublikasi ke publik melalui beberapa media sosial antara lain Facebook, Instagram dan WhatsApp.

\section{PEMBAHASAN}

\section{Pembuatan Skrip Video}

Sebelum dilakukan pengambilan video, Tim melakukan meeting untuk mendesain alur (story board) video yang akan dibuat. Hasil diskusi tim memutuskan akan menampilkan Dekan Fakultas Teknik sebagai peran utama video untuk memberiakn eduksi mengenai hal-hal terkait pencegahan penyebaran virus corona dan 5 orang mahasiswa sebagai aktor pendukung. Opening Video akan 
ditampilkan berita-berita media terkait perkembangan virus corona di wilayah Provinsi Maluku Utara dan video lokasi Fakultas Teknik Universitas Khairun.

\section{Tahapan Pengambilan Video}

Pada tahapan ini dilakukan beberapa pengambilan Scene Video antara lain:

1. Pengambilan Video di Kampus Universitas Khairun dan Fakultas Teknik Proses Pengambilan Video dilakukan selama 2 hari di Fakultas Teknik Universitas Khairun. Pengambilan Video pertama dilakukan dengan menggunakan Drone dan digital kamera yang memperlihatkan kondisi Universitas Khairun pada masa pandemik. Video ini akan menjadi video pembuka dengan ditambahkan beberapa potongan video tentang berita terkini perkembangan covid 19 di Indonesia dan Maluku Utara khususnya.

2. Pengambilan Video beberapa Mahasiswa yang memberikan Edukasi kepada masyarakat.

Sebanyak 7 orang mahasiswa dilibatkan dalam video edukasi ini. Konten video diawali dengan beberapa berita tentang penyebaran virus corona di Indonesia dan Maluku Utara, sehingga berimbas pada penutupan kampus. Edukasi tentang tidak menyentuh atau memegang sembarangan, jaga jarak, mencuci tangan dengan sabun pada air mengalir atau dengan hand sanitizer serta tidak bepergian keluar kota atau pulang kampung selama masa pandemik juga ditampilkan dalam video.

3. Pengambilan Video Himbauan Pencegahan COVID 19 oleh Dekan Fakultas Teknik Universitas Khairun yang di wakili oleh Pembantu Dekan III Fakultas Teknik.

Mewakili Dekan Fakultas Teknik Universitas Khairun, Nani Nagu, ST., MT. Pembantu Dekan III memberikan beberapa himbauan 3M kepada para mahasiswa serta informasi kuliah secara daring selama masa pandemik.

4. Pengambilan Video Masyarakat yang terinfeksi dan terdampak COVID 19

Video masyarakat terdampak Covid diambil dari potongan-potongan berita pada Media Nasional, khususnya penambahan jumlah kasus Corona di Wilayah Maluku Utara.

\section{Video Editing}

Setelah seluruh scene video diambil maka tahapan selanjutnya adalah video editing. Adapun software yang dipakai dalam melakukan editing video COVID 19 ini adalah software Adobe Premiere. 
Pada beberapa scene video yang telah diambil selesai pada tahap ini di lakukan penggabungan dan editing video-video yang telah diambil. Hasil editing video edukasi Covid 19 diperoleh durasi video 6,28 menit.

\section{Publishing}

Video COVID 19 yang telah selesai dibuat tentunya akan dipromosikan atau disebarkan melalui media sosial antara lain:

Youtube

(https://www.dropbox.com/s/4f97y4yhhlw485q/Screenshot\%202020-0530\%2017.08.16.png?dl=0), Facebook Fakultas Teknik Unkhair dan instagram.
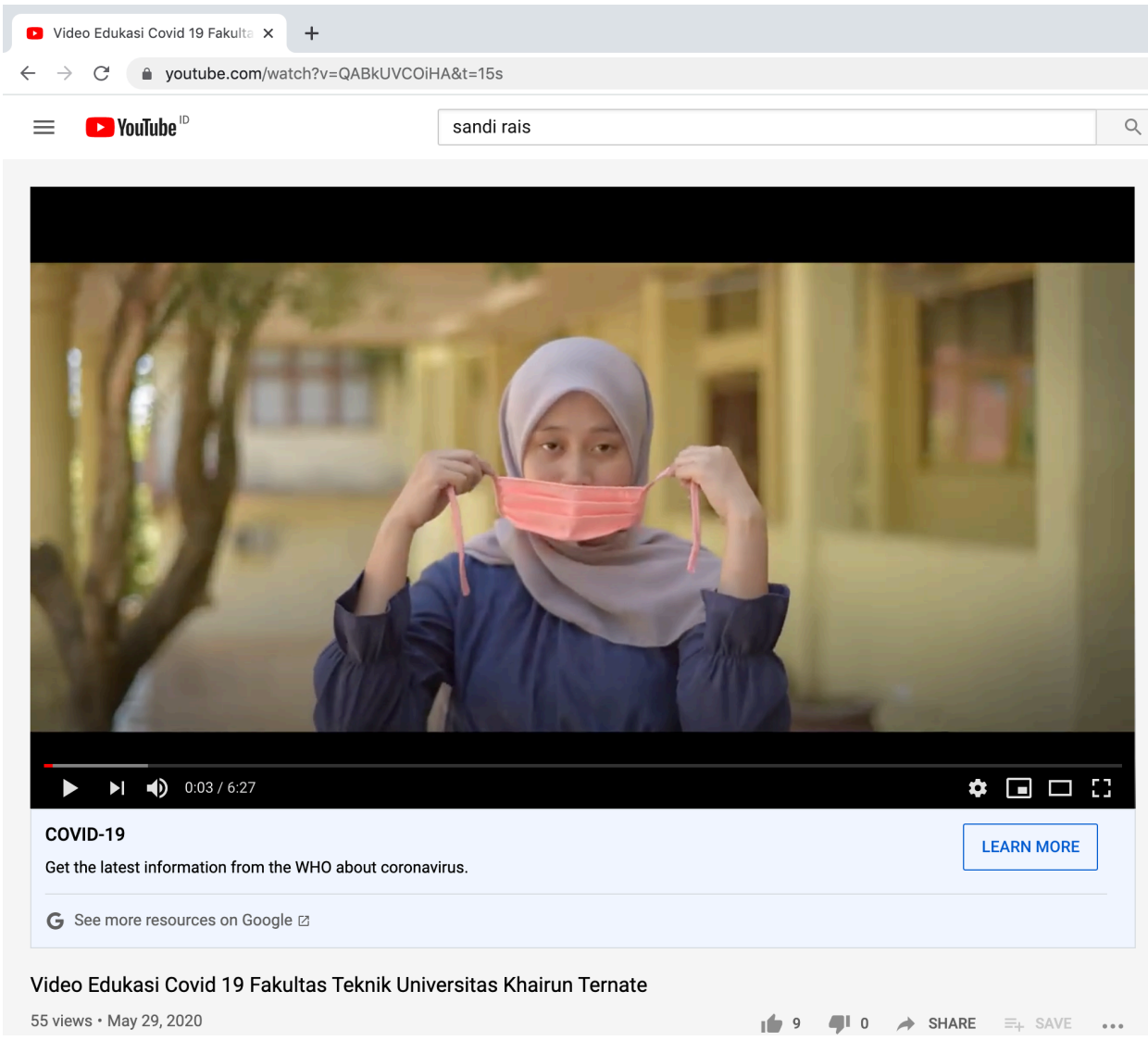

Gambar 1. Tampilan YouTube Video Edukasi Covid 19

\section{Video Respond dan Feedback}

Video edukasi Covid 19 mulai dipublish pada media sosial pada 29 Mei 2020. Pada Media youtube video ini telah dilihat oleh 111 viewers dengan 15 like namun tidak mendapatkan komentar dari nitizen. Minimnya jumlah viewer, like dan komen disebabkan karna video ini di publish pada akun personal dari salah satu penulis yang tidak memiliki banyak pengikut atau subscriber. Respon positif 
diperoleh pada media Instagram dan facebook dimana video ini telah di share oleh beberapa akun instagram (instagram story) dan facebook. Melalui instruksi Dekan Fakultas Teknik, link video ini akan di share ke beberapa group dosen dan mahasiswa agar lebih banyak dilihat. Publikasi pada website Universitas Khairun dan LPPM Unkhair juga saat ini sedang didiskusikan untuk segera di publish. Pengabdian ini sejalan dengan penelitian. Hal ini didukung penelitian yang dilakukan oleh (Tulloch, 2020), hasil penelitiannya bahwa penyampaian edukasi melalui pesan multimedia mudah dan cepat dicerna, termasuk oleh masyarakat yang tidak melek huruf atau mereka yang tidak terbiasa berkonsentrasi pada komunikasi berbasis teks untuk waktu yang lama. Hal ini juga sejalan dengan penelitian yang dilakukan oleh (Hidayati, 2016), menyatakan bahwa peningkatan pengetahuan secara signifikan setelah diberikan video, hal ini dikarenakan video menambah pengetahuan.

\section{SIMPULAN}

Kegiatan pembuatan video edukasi covid 19 Fakultas Teknik telah selesai dilaksanakan dengan melibatkan unsur pimpinan dan 5 orang mahasiswa Fakultas Teknik Universitas Khairun. Saat ini Video tersebut telah di publikasikan melalui media Youtube dengan link akses (https://www.dropbox.com/s/4f97y4yhhlw485q/Screenshot\%202020-05-30\%2017.08.16.png?dl=0.

Selain youtube video ini juga dipublikasi ke Facebook Fakultas Teknik Universitas Khairun dan beberapa Instagram Dosen dan Mahasiswa. Video ini berisi anjuran tentang cara-cara pencegahan penyebaran virus corona antara lain; mencuci tangan dan menggunakan hand sanitaiser secara teratur, menjaga jarak saat berada diluar rumah, menggunakan masker, mengkonsumsi vitamin, serta anjuran untuk dirumah saja. Selain itu juga beberapa bantuan sembako kepada para mahasiswa yang terdampak Covid 19 dan penyampaian untuk bekerja dan belajar dari rumah juga ditampilakan dalam video ini.

Hasil publishing pada media youtube, sebanyak 111 orang telah melihat video ini dan 15 orang memberikan like namun tidak ada komentar. Hal ini disebabkan karena video ini di publish pada akun personal dari salah satu penulis yang tidak memiliki banyak pengikut atau subscriber. Respon positif diperoleh pada media Instagram dan Facebook dimana video ini telah di share oleh beberapa akun Instagram (Instagram story) dan Facebook. Melalui instruksi Dekan Fakultas Teknik, link video ini akan di share ke beberapa group dosen dan mahasiswa agar lebih banyak dilihat. Publikasi pada website Universitas Khairun dan LPPM Unkhair juga saat ini sedang didiskusikan untuk segera dipublikasi. 


\section{UCAPAN TERIMA KASIH}

Terima Kasih Kepada LPPM Universitas Khairun yang telah membiayai kegiatan Program Pengabdian Masyarakat Mandiri tahun 2020.

\section{DAFTAR PUSTAKA}

Azhar Arsyad. 2004. Media Pembelajaran. Jakarta: PT. Raja Grafindo Persada.

Buana, D. 2020. Analisis Perilaku Masyarakat Indonesia dalam Menghadapi Pandemi Virus Corona (Covid-19) dan Kiat Menjaga Kesejahteraan Jiwa. Jurnal sosial dan budaya syar-i, 7(3),1-14.

Cheppy Riyana. 2007. Pedoman Pengembangan Media Video. Jakarta: P3AI UPI.

Tulloch, O. 2020. Key considerations: online information, mis and disinformation in the context of COVID-19 (March 2020). Diakses pada 12 Mei 2020, dari: https://www.socialscienceinaction.org/wp -content/uploads/2020/03/SSHAPBrief.OnlineInformation.COVID-19.pdf

Situasi Virus Corona (Covid 19) Indonesia, WWW.Covid19.co.id, Di akses pada tanggal: 22 April, 2020.

Kasus corona bertambah, warga diminta tidak mudik. Artikel www.kompas.com, 07 April 2020. Diakses pada tanggal 22 April, 2020. 